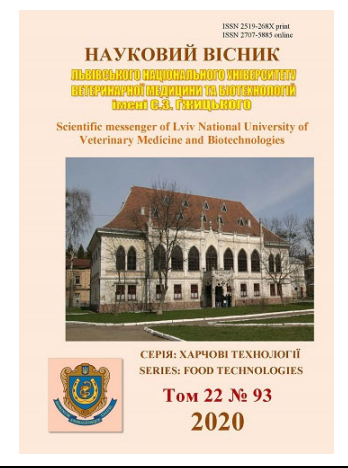

Науковий вісник Дьвівського національного університету ветеринарної медицини та біотехнологій імені С.3. Гжицького. Серія: Харчові технології

\author{
Scientific Messenger of Lviv National University \\ of Veterinary Medicine and Biotechnologies. \\ Series: Food Technologies
}

UDC 621.914.6: 621.833

\title{
Modeling of the worm cutter in the process of cutting the gears
}

\author{
I. E. Grycai, V. I. Topchii, I. G. Svidrak \\ National University “Lviv Polytechnik”, Lviv, Ukraine
}

Article info

Received 27.01.2020

Received in revised form 27.02.2020

Accepted 28.02.2020

University "Lviv Polytechnic",

S. Bandera Str., 12, Lviv,

79013, Ukraine.

Tel.: +38-066-229-50-87

E-mail:svidrak99@gmail.com
Grycai, I. E., Topchii, V. I., \& Svidrak, I. G. (2020). Modeling of the worm cutter in the process of cutting the gears. Scientific Messenger of Lviv National University of Veterinary Medicine and Biotechnologies. Series: Food Technologies, 22(93), 39-44. doi: 10.32718/nvlvet-f9307

This work offers a new approach to graphical modeling of worm cutter parameters, based on analyses and synthesis of simple kinematic movements, causing its cutting elements a single move and displacement when placing metal into a hollow between spikes of the gear, which is being cut. It is one of the most difficult cutting and shaping processes, combining four kinematic movements - rotation of the cutters, their axial feed, rotation of the billet and a constructive move - displacement of cutting elements, located on the principle worm helix along the cutter axis. The modeling difficulty is that the cutting surface constantly changes its location and form in relation to the spikes. This surface is formed on the billet as a kind of a transition surface between the untreated surface, the partly treated surface and the partly treated hollow between the spikes of the gear, which is being cut. Its formation is participated by all the spikes, which have performed the cutting during all the time before a certain moment. Continuous change of the transition surface shape and size determines the shape and size of the shavings and the cross-sectional parameters of the spikes slices and the tool blades, and its reproduction is a base for a correct quantitative assessment of the cutting parameters of individual blades and spikes of the cutter. In its turn, complete and authentic information about the cross-sections and the shape and size of metal layers cut during the spike milling is a base for calculating and analysis of the cutting power, the friction force, the thermal processes, fluctuations and vibrations. The algorithm of an instant surface formation between the gear spikes and the shavings $3 D$ geometry on all of the active spikes of the tool are realized in AutoCAD graphic system. Here are given the results of computer modeling of the shavings when using the Archimedean cutter with counter feed. Complete information about geometrical structure of the cut off layers creates the base for a detailed and system modeling of this process abreast the separate warm cutter rails, the spikes and the blades. In combination with intensity of the plastic deformation data, the tension and the temperature received in Deform system for a certain spike milling condition, the parameters of the cut layers data referred in this work, create the condition for thermo prognostication and the cutting elements waste, their power load, strength protective coatings, cutting force and temperature transition processes, optimum technological processes of spike milling projecting and its managing.

Key words: milling metal processing, milling cutter, cut, transition, surface, toroidal profile, algorithm, solid state modeling.

\section{Моделювання зрізів черв'ячної фрези в процесі нарізання зубччастих коліс}

\author{
I. Є. Грицай, В. І. Топчій, І. Г. Свідрак
}

Національний університет “Львівська політехніка”, м. Львів, Украӥна

У роботі пропонується новий підхід до графічного моделювання параметрів зрізів черв 'ячної фрези, який базується на аналізі та синтезі елементарних кінематичних рухів, приведених до одиничних посувань $і$ переміщень ї̈ різальних елементів в процесі усування металу у западинах між зубиями колеса, яке нарізають. Цей процес належить до найскладніших процесів різання та формоутворення, який поєднує чотири кінематичних рухи - обертання фрези, ї̈ осьову подачу, обертання заготовки колеса та конструктивний рух - перемішення різальних елементів фрези, розташованих на гвинтовій поверхні основного черв яка, вздовж осі фрези. Складність моделювання полягає у тому, щчо поверхня різання неперервно змінює своє розташування та форму стосовно зубців фрези. Ця поверхня формується на заготовці, як деяка перехідна поверхня між ще необробленою поверхнею та частково 
обробленою западиною між зубиями колеса, яке нарізають. Участь у ї̈ утворенні беруть усі зубиі, які здійснювали різання за весь час, щзо передує якомусь певному моменту. Неперервна зміна форми та розмірів перехідної поверхні визначає форму та розміри стружок і параметри перерізу зрізів зубців та лез інструменту, а ї̈ відтворення є основою для правильної кількісної оцінки параметрів зрізів окремих лез та зубців фрези. У свою чергу, повна та достовірна інформація про перерізи зрізів і форму та розміри шарів металу, які зрізаються в прочесі зубофрезерування, є основою для розрахунку та аналізу сил різання, тертя, теплових процесів, коливань та вібрацій. Алгоритм формування миттєвої перехідної поверхні між зубцями колеса $і$ 3D геометрії стружок на усіх активних зубиях інструменту реалізований у графічній системі АитоСАD. Наведено результати комп 'ютерного моделювання стружок при різанні аріхмедовою фрезою з зустрічною подачею. Повна інформація про геометричну структуру зрізуваних шарів створює основу для комплексного і системного моделювання иььго процесу на рівні окремих рейок, зубців та лез черв 'ячної фрези. В поєднанні з даними про інтенсивність пластичного деформування, напруження і температуру, отриманих для відповідних умов зубофрезерування в системі Deform, дані про параметри зрізуваних шарів, які наводяться у роботі, створюють умови для прогнозування теплоти і зношування різальних елементів фрези, їх силового навантаження, міцності захисних покрить, перехідних процесів сили різання і температури, проектування оптимальних технологічних процесів зубофрезерування $і$ керування циим процесамu.

Ключові слова: фрезерна металообробка, черв'ячна фреза, зріз, перехідна поверхня, тороїдний профіль, алгоритм, твердотільне моделювання.

\section{Вступ}

Зубчасті колеса та передачі є невід'ємними складовими сучасних механізмів і машин, а обсяги їх щорічного виробництва в різних галузях машинобудування складають мільйони одиниць. Основним способом нарізання зубчастих коліс в усіх організаційнотехнічних типах виробництва у наш час $є$ зубофрезерування коліс черв'ячними модульними фрезами.

Цей процес належить до найскладніших процесів різання та формоутворення, який поєднує чотири кінематичні рухи - обертання фрези, ії осьову подачу, обертання заготовки колеса та конструктивний рух переміщення різальних елементів фрези, розташованих на гвинтовій поверхні основного черв'яка, вздовж осі фрези. Складність моделювання полягає у тому, що поверхня різання неперервно змінює своє розташування та форму стосовно зубців фрези. Ця поверхня формується на заготовці, як деяка перехідна поверхня між ще необробленою поверхнею та частково обробленою западиною між зубцями колеса, яке нарізають. Участь у ії утворенні беруть усі зубці, які здійснювали різання за весь час, що передує якомусь певному моменту. Неперервна зміна форми та розмірів перехідної поверхні визначає форму та розміри стружок і параметри перерізу зрізів зубців та лез інструменту, а ii відтворення $\epsilon$ основою для правильної кількісної оцінки параметрів зрізів окремих лез та зубців фрези. У свою чергу, повна та достовірна інформація про перерізи зрізів і форму та розміри шарів металу, які зрізаються в процесі зубофрезерування, є основою для розрахунку та аналізу сил різання, тертя, теплових процесів, коливань та вібрацій.

\section{Матеріал і методи досліджень}

Під час нарізання зубчастих коліс форма та розміри перерізів зрізів впливають на силу різання, величину пружних деформацій зубофрезерного верстата, інтенсивність зношування інструмента, а в кінцевому підсумку - на точність та продуктивність обробки. Зважаючи на важливість інформації про параметри зрізів для оптимізації процесів виготовлення зубчастих коліс, відомі результати численних пошуків у цій галузі. Проте, більшість відомих досліджень присвячені моделюванню певних аспектів роботи черв'ячних фрез та окремих параметрів зрізів без проведення комплексних досліджень. Найскладнішим завданням при встановленні параметрів зрізів є виявлення форми та розмірів перехідної поверхні між сформованою черв'ячною фрезою западиною між зубцями та необробленою поверхнею заготовки. Складність описання та відтворення даної поверхні призводить до спрощення дійсних закономірностей формоутворення, а це, в свою чергу, зменшує точність розрахунків.

Серед багаточисельних наукових праць, присвячених цій проблемі, можна виділити декілька 3 них, в яких наведено методику та результати моделювання параметрів зрізів черв'ячної фрези на основі 3D графічного відтворення слідів різальних елементів за допомогою CAD систем (Bouzakis et al., 2002; Vasilis et al., 2007). В цих працях на основі використання можливостей комп'ютерних систем інженерної графіки зображено кільцевий рух контуру зубця фрези при обертанні навколо іiї осі, тобто, поверхня різання певного зубця. Накладання траєкторій обертання рухів окремих зубців в фіксованих положеннях виробничої поверхні фрези дозволило частково описати перехідну поверхню і визначити об'ємну форму зрізів зубців в різних ділянках активної частини черв'ячної фрези. Проте, усі чотири кінематичні рухи, які мають місце в процесі різання-формоутворення в цих працях не враховано, тому форма перехідної поверхні, а також об'ємна геометрія стружок, які зрізають зубці фрези, не відповідають їх дійсним параметрам.

Найбільш комплексним серед відомих методів дослідження параметрів зрізів черв'ячної фрези можна вважати метод В. Н. Башкірова, результати моделювання на основі якого наведені у роботі (Bashkirov \& Serova, 1984). Проте, у даному методі перехідна поверхня розглядається як еквідистанта до евольвент профілів, що підлягають обробці. Така умовність певною мірою допустима лише для випадку напівчистової або чистової обробки зубчастих коліс, коли черв'ячна фреза здійснює різання у попередньо сформованих западинах між зубцями. Для умов різання на повну глибину або для першого (чорнового) проходу, коли зрізаються найбільші шари металу заготовки, а процес різання супроводжується інтенсивним тепловиділенням, зношуванням інструмента та пружними деформаціями, таке припущення не відображає реально- 
го стану та не відповідає закономірностям формоутворення в умовах обкочування.

3 огляду на розповсюдження та значення зубофрезерного процесу у сучасному машинобудуванні, в працях низки авторів, зокрема (Тајс, 1972; Saharov, 1982), кінематика процесу представлена траєкторією руху окремого зубця в обертанні навколо осі фрези, а також відтворення руху зубців, які передували різанню даного зубця в положеннях по осьовій подачі. Проте цей підхід автори не поширюють на обкочування, яке є частиною кінематики процесу зубофрезерування; у вказаних працях цей рух розглядається як “позиції генерування” у виді перерізу траєкторії зубця площиною міжцентрового перпендикуляру. Попри позитивні ідеї, які містять ці дослідження, вони не дають змоги повною мірою та адекватно відтворити перехідну поверхню і параметри зрізуваних шарів.

\section{Результати та їх обговорення}

Метою дослідження у даній роботі є розробка методики побудови твердотільних моделей зрізів черв'ячної фрези при нарізанні прямозубих зубчастих коліс в середовищі графічної системи AutoCAD. У задачі дослідження входили наступні етапи:

- аналіз літературних джерел у галузі створення комп'ютерних моделей процесу стружкоутворення при зубофрезерній обробці зубчастих коліс;

- розробка алгоритму визначення утворення геометричної форми та розмірів перехідних поверхонь і зрізів з урахуванням усіх фізичних рухів та поверхонь різання при формоутворенні евольвентного профілю зубчастого вінця колеса;

- вивчення інструментальних засобів графічної системи AutoCAD для реалізації запропонованого алгоритму побудови твердотільної моделі зрізу;

- моделювання твердотільних об’єктів 3 тороїдальними і циліндричними поверхнями з забезпеченням взаємного розташування технологічної пари - “фреза - зубчасте колесо".

\section{Результати моделювання зрізів}

Основну інформацію про процес різання черв'ячної фрези, необхідну для його всебічного та повного аналізу, містять геометричні параметри зрізів. Зокрема, від геометричних параметрів зрізів залежать:

- сила різання та іiі нерівномірність за оберт фрези (динамічні навантаження на компоненти верстата);

- сили тертя на передній та задній поверхнях лез;

- робота різання;

- нагрівання та температура різання;

- зношування зубців (стійкість черв'ячної фрези);

- перехідні процеси сили і температури різання, пружні деформації та вібрації зубофрезерного верстата;

- невільне різання та його вплив на процес зубофрезерування.

Головною умовою точного визначення параметрів зрізів є встановлення форми та розмірів поверхні, яка утворюється в процесі усталеного різання в кожній западині зубчастого колеса між обробленими зубцями та необробленою поверхнею заготовки. Ця поверхня формується усіма активними зубцями i лезами черв'ячної фрези в результаті осьової подачі, обкочування і осьового (конструктивного) руху гвинтової поверхні фрези. В межах цієї перехідної поверхні кожний наступний цикл різання в одній западині продовжується після оберту заготовки зі столом верстата і переміщення фрези на величину осьової подачі. Ця перехідна поверхня западини визначає дійсну форму i розміри миттєвого перерізу зрізу, які непевно змінюються за кутом повороту зубця, та періодично повторюються в циклі зубофрезерної обробки.

Під час осьового переміщення черв'ячної фрези іiі кожне лезо здійснює обертальний рух по однаковій траєкторії, займаючи одне і те ж положення відносно елементарної поверхні нарізуваного профілю. Інакше кажучи, внаслідок жорсткого кінематичного зв'язку між робочими рухами різання i формоутворення в процесі зубофрезерування, під час кожного різу лезо зубця фрези перебуває у контакті із утворюваним профілем один раз за період одного оберту зубчастого колеса, а поверхня різання леза залишається незмінною для даних початкових умов. Періодичний контакт кожного леза з заготовкою поєднується з неперервністю різання і формоутворення в процесі обкочування завдяки конструктивному руху основного черв'яка, на якому утворено зубці фрези, та осьової подачі.

На рис. 1 представлена модель взаємного розташування фрези та заготовки зубчастого колеса в процесі нарізання його вінця з вказанням їх робочих рухів.

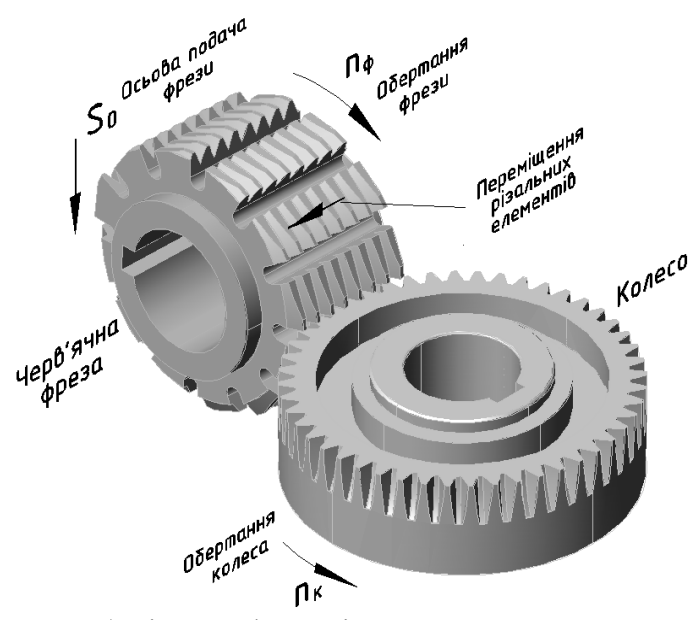

Рис. 1. Робочі рухи фрези і заготовки колеса в процесі зубофрезерної обробки

Для моделювання геометрії стружок, які зрізають леза фрези, необхідно відтворити множину усіх поверхонь різання зубців фрези, які здійснювали різання в кожній западині протягом часу іiі формоутворення. Саме зовнішні границі цих поверхонь, з урахуванням ïx взаємного накладання i перетину при поєднанні чотирьох кінематичних рухів заготовки і інструменту, визначають геометричну структуру стружки.

В основу аналізу закономірностей моделювання миттєвої перехідної поверхні в довільній западині між зубцями колеса, яке обробляють зубофрезеруванням, покладено наступні положення. 
Стружка, яку усуває із западини кожен зубець фрези на гвинтовій поверхні, обмежена:

- поверхнею різання, яка є однаковою для усіх зубців, що побудовані на основі єдиного початкового контуру;

- зовнішньою циліндричною поверхнею заготовки, яка залежить від позиції кожного зубця на активній довжині фрези;

- сукупністю поверхонь різання усіх зубців, які здійснювали різання у даній западині між зубцями перед біжучим зубцем.

Поверхня різання черв'ячної фрези утворюється трапецевидним профілем зубця початкового контуру і $\epsilon$ поверхнею обертання цього контуру навколо осі фрези. Межі поверхні різання кожного зубця обмежені зовнішньою циліндричною поверхнею зубчастого колеса, яке нарізають, а границі цих меж визначаються положенням даного зубця на активній довжині фрези.

Кожен зубець фрези здійснює різання стосовно однієї западини між зубцями колеса в одному і тому ж місці; за один оберт фрези для даного зубця міняється западина, але параметри зрізів даного зубця: дуга контакту з заготовкою, форма і розміри стружки - для цього зубця залишаються незмінними (це положення не стосується випадків зубофрезерування з діагональною подачею або 3 періодичними переміщеннями фрези в осьовому напрямку) (рис. 2).

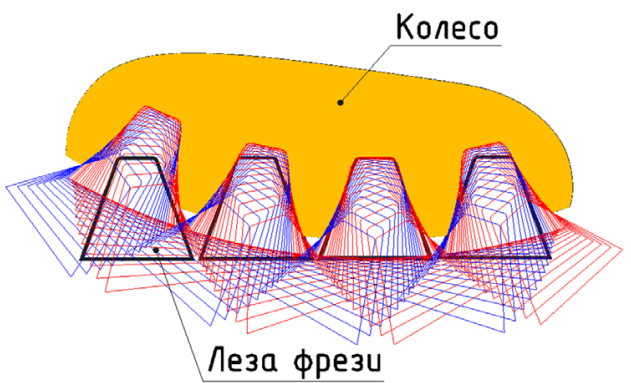

Рис. 2. Границі профілів зубців фрези та колеса, які обробляються в різних позиціях різання

Неперервні кінематичні рухи різання можна розглядати як їх елементарні складові. Першим елементарним рухом є оберт фрези на один кутовий крок $\tau$ :

$$
\tau=\frac{360^{\circ}}{Z_{\phi}},
$$

де $Z_{\phi}$ - кількість рейок фрези.

За час цього оберту колесо повертається на кут профілювання $\psi$ :

$$
\psi=\frac{360^{\circ}}{Z \cdot Z_{\phi}},
$$

де $Z$ - кількість зубців колеса.

За цей же час точка на гвинтовій поверхні фрези переміститься вздовж іiі осі на величину одиничного переміщення $\Delta \mathrm{x}$ :

$$
\Delta x=\frac{\pi \cdot m}{Z_{\phi}},
$$

де $m$ - модуль зубчастого колеса.

Наведені миттєві положення колеса та різальних тороїдальних елементів фрези з врахуванням іiі осьо- вої подачі були покладені в основу моделювання зрізів в середовищі графічної системи AutoCAD.

Першим миттєвим положенням тороїда після певного часу врізання фрези в заготовку колеса по осьовій подачі $є$ тороїд 3 індексом “ $I$ ” (рис. 3). Другим положенням $є$ попередній найближчий на гвинтовій поверхні тороїд, який вже здійснив різ. Тороїд цього зубця з індексом “II" зміщено по осі фрези на величину одиничного лінійного переміщення $\Delta x$ гвинтової поверхні черв'яка фрези у напрямку, протилежному до переміщення гвинтової поверхні черв'яка та повернуто на одиничний кут профілювального різання $\psi$ у напрямку обертання зубчастого колеса (рис. 3). Третім положенням тороїда фрези з індексом “III” $є$ положення, коли вона прорізала западину в колесі в іiі попередньому по осьовій подачі положенні; цей тороїд зміщено у напрямку, зворотному до вектора осьової подачі на величину осьової подачі $S_{o}$ (рис. 4). Четвертим положенням з індексом “ $I V$ ”' $є$ тороїд зубця фрези наступного по відношенню до “III” на гвинтовій лінії; його тороїд зміщено по осі фрези на величину одиничного лінійного переміщення $\Delta x$ гвинтової поверхні черв'яка фрези у напрямку переміщення гвинта та повернуто на одиничний кут профілювального різання $\psi$ у напрямку, зворотному до обертання колеса (рис. 4).

Об'єднання чотирьох тороїдів “I”, “II”, “III” та “ $I V$ ” надає можливість сформувати поверхню різання окремого зубця, перехідну поверхню і об'ємний контур стружки, яку зрізає цей зубець фрези (рис. 5).

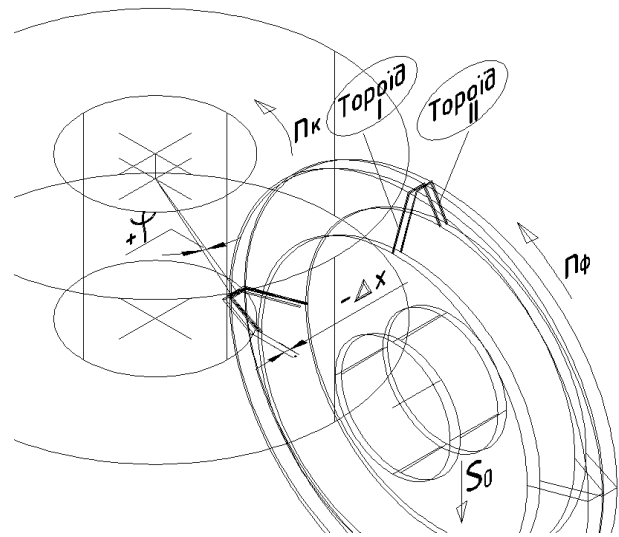

Рис. 3. Розташування тороїдів фрези "I" і “ $I T$ " відносно колеса

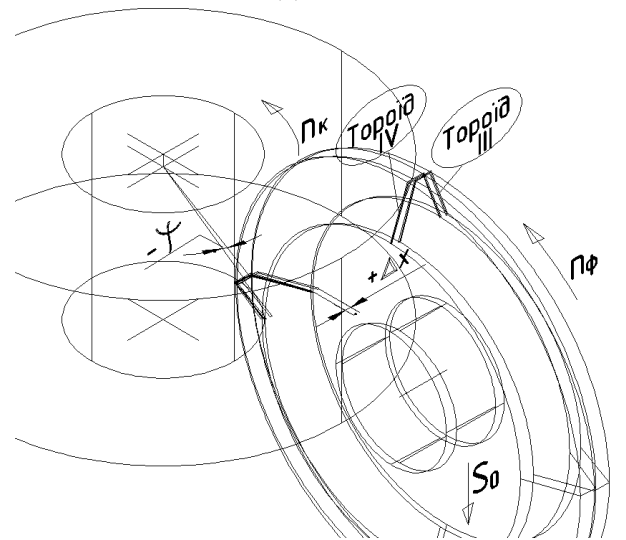

Рис. 4. Розташування тороїдів фрези “ $I I I$ ” і “ $I V$ ” відносно колеса 


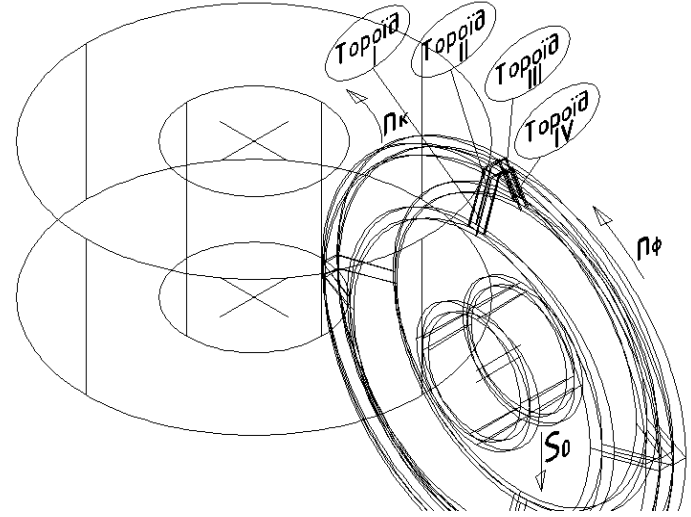

Рис. 5. Вигляд композиції чотирьох тороїдів "I", “ $I I$ ”, "III", "IV"
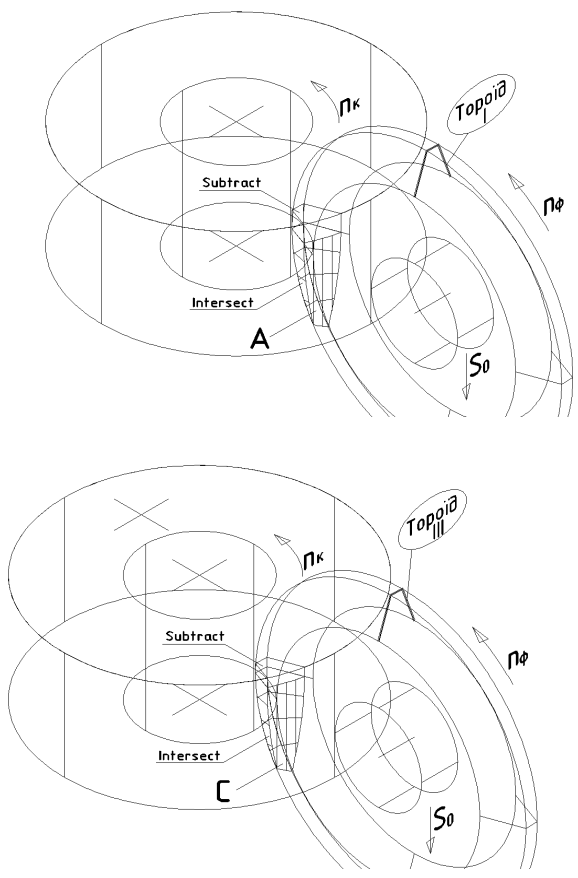

Для моделювання зрізу черв'ячної фрези застосовувалися булеві процедури віднімання (SUBTRACT) i перетину (INTERSECT) графічної системи AutoCAD. За допомогою процедури SUBTRACT відокремлювалася ділянка колеса, яку фреза вже прорізала в осьовій подачі і яка не приймала участі у формоутворенні зрізу. 3 застосовуванням процедури INTERSECT будувалося тіло, спільне для колеса і відповідного тороїда фрези в зоні різання. Таким чином, визначилися чотири тіла А, В, С і D (рис. 6).

Модель зрізу будувалася як різниця об'єму тіла A i суми об'ємів тіл В, С і D з застосуванням процедури віднімання (SUBTRACT) (рис. 7). Збільшене зображення твердотільної моделі зрізу представлене на рис. 8.
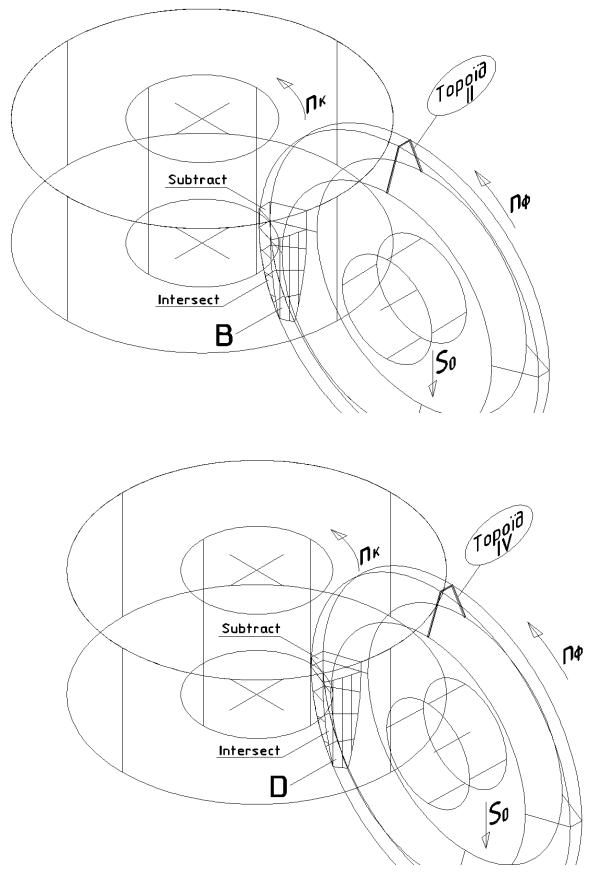

Рис. 6. Моделювання зрізу черв'ячної фрези

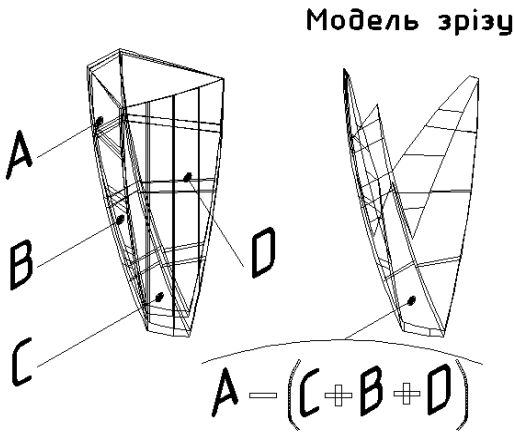

Рис. 7. Побудова моделі зрізу

\section{Висновки}

1. В роботі запропоновано алгоритм визначення форми та розмірів перехідних поверхонь i зрізів черв'ячної фрези з врахуванням усіх рухів та поверхонь різання, які приймають участь у формоутворенні евольвентного профілю зубчастого вінця колеса.

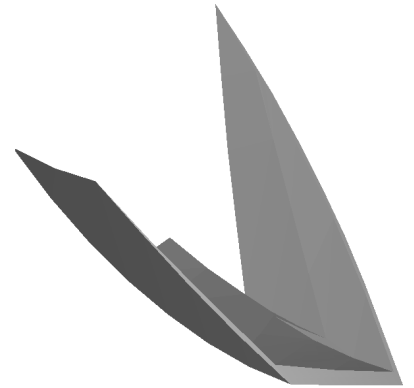

Рис. 8. Зображення моделі зрізу

2. Розроблені методика та алгоритм побудови моделі зрізу черв'ячної фрези в системі AutoCAD, що дозволяє використати отримані дані для аналізу зрізуваних шарів в інших умовах процесу неперервного обкочування - нарізання черв'ячних коліс, циліндричних та конічних коліс з гвинтовими зубцями, шліцьових валів тощо. 
Перспективи подальиих досліджень. Результати моделювання геометричних параметрів зрізів в AutoCAD дозволяють їх застосувати в системі реологічного моделювання процесу різання Deform i визначити такі властивості процесу, як інтенсивність зсуву, напруження та температуру для заданих початкових умов (подачі, глибини різання) i закономірності їх зміни по шляху різання, міцності матеріалу заготовки та інструментального матеріалу фрези. Поєднання результатів цих двох систем створює широкі можливості для комплексного та системного дослідження процесу зубофрезерної обробки, зокрема, силового просторового навантаження, нагрівання та зношування черв'ячної фрези, перехідних процесів сили різання та їх впливу на виникнення коливань в пружній системі верстату, міцності захисних покрить фрези тощо.

\section{References}

Bashkirov, V. N., \& Serova, A. A. (1984). Opredelenie sechenija srezov pri zubonarezanii cilindricheskih koles chervjachnoj frezoj. Stanki i instrument, 1, 1820 (in Russian).

Bouzakis, K.-D., Kombogiannis, S., Antoniadis, A., \& Vidakis, N. (2002). Gear Hobbing Cutting Process Simulation and Tool Wear Prediction Models: Journal of Manufacturing Science and Engineering, 124(1), 42-51. doi: 10.1115/1.1430236.

Saharov, A. Z. (1982). Issledovanie processa zubofrezerovanija kosozubyh koles mnogozahodnymi chervjach-nymi frezami. V kn.: Progressivnye processy mashinostroenija. Mehved. sb. nauch. trudov. VolgPJa. Volgograd, 31-38 (in Russian).

Tajc, B. A. (1972). Tochnost' i kontrol' zubchatyh koles. M.: Mashinostroenie (in Russian).

Vasilis, D., Nectarios, V., \& Aristomenis, A. (2007). Advanced Computer Aided Design Simulation of Gear Hobbing by Means of Three-Dimensional Kinematics Modeling. Journal of Manufacturing Science and Engineering, 129(5), 911-918. doi: $10.1115 / 1.2738947$. 